\title{
Pathways to an oil-constrained sustainable city
}

\author{
R. J. Brewster \\ Faculty of Society and Design, Bond University, Australia
}

\begin{abstract}
The global production of conventional oil is predicted to have reached a peak plateau in the first decade of this century and will gradually decline, while demand outstrips the discovery and exploitation of new oil sources. Current oil strategies are geared to mitigation actions, but adaptive measures will become more important in the longer term future as oil supply becomes constrained. This paper reports the grounded theory research of a $\mathrm{PhD}$ investigation into adapting urban residential development to an oil-constrained future, in the Australian and wider context. The planning research is grounded in a general theoretical framework of sustainable development theory, encompassing urban metabolism and material flow analysis. European pre-oil economy cities form the basis for development of four grounded theories and a conceptual framework model about the characteristics of an oil-constrained sustainable city. The framework provides the basis of a tool for integrating the effects of oil constraints into the urban metabolism for sustainable planning and development. These theories and model will assist spatial planners to guide transformation of urban residential forms towards a transitional city of tomorrow and an oil-constrained city of the future.
\end{abstract}

Keywords: oil depletion, urban metabolism, urban morphology, pre-oil economy cities, sustainable urban design.

\section{Introduction}

The twentieth century has been the era of abundant supplies of oil (petroleum) and the century of the motor car (automobile). Cheap petrol (gasoline) has been a significant catalyst for expansion of cities into suburbs [1]. The urban form of once compact cities has bloated into sprawling road and motor vehicle dominated metropolitan regions [2,3]. Oil has become fundamental to every facet of modern civilisation. Droege [4] contends that 'it is difficult to overstate the significance of black gold in defining virtually everything that cities are today: spatially, 
economically and culturally.' The issues of oil depletion and climate change are seen as two of the key global problems of this century: cities 'now consume $75 \%$ of the world's energy and emit $80 \%$ of the world's green-house gases' [5]. Adapting to oil depletion has benefits for climate change [6].

The International Energy Agency (IEA) World Energy Outlook 2010 [7] acknowledged that global conventional crude oil output had peaked in 2006 at 70 million barrels per day $(\mathrm{mb} / \mathrm{d})$, but noted unconventional sources were growing strongly to maintain a steady total oil output of $86 \mathrm{mb} / \mathrm{d}$. The IEA World Energy Outlook 2013 [8] confirms a 6\% decline rate in existing conventional oil fields and a fall in output of over $40 \mathrm{mb} / \mathrm{d}$ by 2035 . While a growing optimism in the USA suggests reliance on shale oil will arrest the decline, continuous drilling investment is required to offset rapid field-level declines. Global oil demand will outstrip the discovery and exploitation of new oil sources. The IEA predicts renewable sources of energy will 'account for nearly half the increase in global power generation to $2035^{\prime}$ ' [8]; of which wind and photovoltaics will be $45 \%$.

The prospect of oil depletion prompted a $\mathrm{PhD}$ investigation by the author into the relationship between oil dependency and urban residential development in the Australian context [3]. Current oil strategies are geared to mitigation actions, but adaptive measures will become much more important in the longer term future as oil supply becomes constrained [6]. The urgency of the research is highlighted by the developed premise that this future will evolve in the lifetime of the post-World War 2 generations. Its importance is grounded in the axiomatic knowledge that our grandchildren will live with the inter-generational consequences.

\section{In search of the sustainable city}

This paper presents a highly condensed version of key elements of the research on adapting urban residential development to an oil-constrained future in the Australian context. The research is grounded in a general theoretical framework of sustainable development theory encompassing urban metabolism [3]. One of the pathways to the oil-constrained future relies on technological solutions to maintain the status quo by exploiting unconventional sources of oil and gas, together with non-depleting energy sources, to meet future global demand for energy and petrochemicals. An alternative pathway may lead to a transformation of cities to grow and function in a sustainable and regenerative manner with less reliance on technology. This section presents that transformative pathway, using a grounded theory approach to examine European cities of the pre-oil economy as a viable basis to reveal characteristics of an analogous oil-constrained sustainable city. It proposes a conceptual framework for oil-constrained sustainable residential urban forms using an urban metabolic approach. Section 3 presents the planning-related characteristics of a sustainable city under a scenario of oil constraints and the four developed theories arising from the analysis.

\subsection{Pre-oil economy sustainable cities}

Cities historically have undergone transformative shifts in changing technological, economic and political circumstances (including major wars). However, many old 
cities are valued as being sustainable and resilient $[9,10]$. Twelve European cities were selected as examples for the study, plus Greenwich Millennium Village London, and Portland, Seattle and Vancouver in North America. A selection preference was for cities with centres intact from World War 2 bombing. Table 1 gives contextual details of most of the European cities and some of the features that are relevant to this research.

In order to be more relevant to the reference Australian coastal City of Gold Coast, the example cities are all connected to water, as semi-coastal or river oriented cities. Inner city populations are in a wide range from 108,000 to 2.2 million, compared with a Gold Coast 2011 census population of 494,500. Paris is by far the largest city, but is included because of the regulated design of the apartment buildings. Most of the old inner city areas have a dense urban form. The selected 'sustainable' features of the cities are framed by enduring qualities of urban design noted by Lynch [11] and others-e.g. Gehl [9], Girardet [10], Krier [12], $\mathrm{Ng}$ [13] and Osmond [14].

In his seminal book Good City Form, Lynch proposes formal qualities of the 'good city': it is vital, sensible, well fitted, accessible, well controlled, and all achieved with justice and internal efficiency. More generally it is 'a continuous, well connected, open place, conducive to development'. Lynch explains these qualities as having characteristics that make it safe, structured and legible; having a form that is adaptable; and accessibility that is diverse and equitable [11]. He illustrates his ideas on urban design with examples from well-known pre-oil economy European cities, including Barcelona, Florence and Paris.

The author considers that whatever was built in the 1800 s period could logically continue to be built with all the advantages of electricity, the technological inventions of electric lifts (elevators) and self-lifting cranes, and significant advances in materials science. However, these materials include petrochemicals such as plastics (e.g. PVC and foam insulation), which could become problematic unless non-petroleum substitutes are developed and scaled up to meet global demand. Hence it is important to keep these factors in mind in assessing sustainable and adaptable features in the urban morphology of pre-oil economy cities that may be relevant to a transformed city in the oil-constrained future. Of course, these cities have evolved in the use of renewable energy, modern technology and transport, so they also provide models of more or less successful transition to the future. Several of the cities are involved in European sustainable city and SmartCities movements [15].

\subsection{Grounded theory analysis of sustainable urban forms}

The open coding resulting from the European pre-oil economy city observations is categorised in Table 2 for the grouping of concepts and their properties to show themes and relationships. Grouping leads to selective categorisation and to determining the 'core variable' [16]. The categorisation structure is arranged as follows (rank 1 is highest according to a subjective ordinal scale of importance):

$$
\text { Data (from multiple sources) } \rightarrow \text { Concepts } \rightarrow \text { Grouping } \rightarrow \text { Group relationships } \rightarrow \text { Rank }
$$


Table 1: Contextual details of cities included in analysis.

\begin{tabular}{|c|c|c|c|c|c|}
\hline \multirow[b]{2}{*}{ Country } & \multirow[b]{2}{*}{ Cities } & \multirow{2}{*}{\begin{tabular}{|c|} 
Dimensions \\
$\begin{array}{c}2012 \text { population, } \\
\text { area, density }\end{array}$
\end{tabular}} & \multicolumn{3}{|c|}{ Sustainable properties } \\
\hline & & & $\begin{array}{c}\text { Focus of city } \\
\text { features }\end{array}$ & $\begin{array}{c}\text { Transport } \\
\text { features }\end{array}$ & $\begin{array}{c}\text { Energy } \\
\text { features }\end{array}$ \\
\hline Austria & $\begin{array}{l}\text { Viennal } \\
\text { Wien }\end{array}$ & $\begin{array}{l}\text { Inner city: 486,000 } \\
\text { Area: } 415 \mathrm{~km}^{2} \\
\text { Inner density: } \\
13,000-22,000 / \mathrm{km}^{2}\end{array}$ & $\begin{array}{l}\text { 1800s period, the } \\
\text { Ringstrasse } \\
\text { Smart city - } \\
\text { Aspern project }\end{array}$ & $\begin{array}{l}\text { Tram, bus, } \\
\text { electric bus } \\
\text { Bike } \\
\text { sharing }\end{array}$ & $\begin{array}{l}\text { Hydro, solar, } \\
\text { wind power. } \\
\text { Biomass } \\
\text { power plant }\end{array}$ \\
\hline France & Paris & $\begin{array}{l}\sim 2,113,000 \text { in } 105 \\
\text { km² central area. }_{\text {Density: average }} \\
21,300 / \mathrm{km}^{2}\end{array}$ & $\begin{array}{l}1800 \text { s period in } \\
20 \text { central } \\
\text { districts called } \\
\text { arrondissements. }\end{array}$ & \begin{tabular}{|l|} 
Metro \\
Light rail \\
Bus \\
Bike share
\end{tabular} & $\begin{array}{l}\text { Solar and } \\
\text { wind power }\end{array}$ \\
\hline France & Orléans & $\begin{array}{l}\text { City: } \sim 114,000 \\
\text { Area: } 27.5 \mathrm{~km}^{2} \\
\text { Density: } 4,155 / \mathrm{km}^{2}\end{array}$ & \begin{tabular}{|l} 
Regional city, \\
1800 s period
\end{tabular} & Tram only & $\begin{array}{l}\text { Solar and } \\
\text { wind power }\end{array}$ \\
\hline Germany & Aachen & $\begin{array}{l}\text { City: } \sim 241,300 \\
\text { City area: } 161 \mathrm{~km}^{2} \\
\text { Density: } 1,492 / \mathrm{km}^{2}\end{array}$ & $\begin{array}{l}\text { Old city, } \\
\text { 1800s period }\end{array}$ & Bus only & $\begin{array}{l}\text { Solar and } \\
\text { wind power }\end{array}$ \\
\hline Germany & Bonn & $\begin{array}{l}\text { City: } ~ 307,500 \\
\text { Area: } 141 \text { km² } \\
\text { Density: } 2,196 / \mathrm{km}^{2}\end{array}$ & $\begin{array}{l}\text { Administrative } \\
\text { former capital, } \\
1800 \text { s period } \\
\end{array}$ & \begin{tabular}{|l|} 
Tram, \\
U-Bahn \\
Bus \\
\end{tabular} & \begin{tabular}{|l} 
European \\
Gold Energy \\
Award 2011 \\
\end{tabular} \\
\hline Germany & Heidelberg & $\begin{array}{l}\text { City: } \sim 150,350 \\
\text { Area: } 109 \mathrm{~km}^{2} \\
\text { City area density: } \\
1,381 / \mathrm{km}^{2}\end{array}$ & \begin{tabular}{|l|} 
Old city, \\
Bahnstadt \\
PassivHaus \\
development
\end{tabular} & Tram, bus & $\begin{array}{l}\text { Solar and } \\
\text { wind power }\end{array}$ \\
\hline Germany & $\begin{array}{l}\text { Freiburg im } \\
\text { Breisgau }\end{array}$ & $\begin{array}{l}\text { City: } \sim 220,000 \\
\text { Area: } 153 \mathrm{~km} 2 \\
\text { City area density: } \\
1,425 / \mathrm{km}^{2}\end{array}$ & $\begin{array}{l}\text { New smart city } \\
\text { overlaying old - } \\
\text { Rieselfeld, } \\
\text { Vauban Quartier }\end{array}$ & Tram, bus & $\begin{array}{l}\text { Solar and } \\
\text { wind power }\end{array}$ \\
\hline Germany & $\begin{array}{l}\text { Munich/ } \\
\text { München }\end{array}$ & $\begin{array}{l}\text { City: } ~ 1,367,000 \\
\text { Area:310km² } \\
\text { Central density: } \\
4,468 / \mathrm{km}^{2}\end{array}$ & $\begin{array}{l}\text { 1800s and new } \\
\text { PassivHaus } \\
\text { development at } \\
\text { Ackermannbogen }\end{array}$ & $\begin{array}{l}\text { Tram, bus } \\
\text { U-Bahn } \\
\text { (metro) }\end{array}$ & $\begin{array}{l}\text { Solar and } \\
\text { wind power }\end{array}$ \\
\hline Italy & $\begin{array}{l}\text { Florence/ } \\
\text { Firenze }\end{array}$ & $\begin{array}{l}\text { City: } ~ 375,000 \\
\text { Area: } 102 \text { km² } \\
\text { Central density: } \\
3,574 / \mathrm{km}^{2}\end{array}$ & $\begin{array}{l}\text { Old city, } \\
\text { 1800s period, } \\
\text { Agenda } 21 \\
\text { implementation }\end{array}$ & $\begin{array}{l}1 \text { Tram line, } \\
\text { bus }\end{array}$ & Solar? \\
\hline Netherlands & Amsterdam & $\begin{array}{l}\text { City: 762,000 } \\
\text { City Area: } 166 \mathrm{~km}^{2} \\
\text { Central density: } \\
4,822 / \mathrm{km}^{2}\end{array}$ & $\begin{array}{l}\text { 1800s period, } \\
\text { Public \& active } \\
\text { transport. Urban } \\
\text { transform project }\end{array}$ & $\begin{array}{l}\text { Tram, bus, } \\
\text { ferry. Bike } \\
\text { sharing and } \\
\text { culture. }\end{array}$ & $\begin{array}{l}\text { Solar and } \\
\text { wind power }\end{array}$ \\
\hline Spain & $\begin{array}{l}\text { Seville/ } \\
\text { Sevilla }\end{array}$ & $\begin{array}{l}\text { City: 700,000 } \\
\text { City area: } 141 \mathrm{~km}^{2} \\
\text { Central density: } \\
4,955 / \mathrm{km}^{2}\end{array}$ & $\begin{array}{l}\text { 1800s period, } \\
\text { southern city in } \\
\text { Mediterranean } \\
\text { hot climate }\end{array}$ & $\begin{array}{l}1 \text { Tram, bus } \\
1 \text { metro line } \\
\text { Bike } \\
\text { sharing }\end{array}$ & $\begin{array}{l}\text { Concentrating } \\
\text { solar thermal } \\
\text { (CST) power; } \\
\text { Wind power }\end{array}$ \\
\hline Switzerland & Zurich & $\begin{array}{l}\text { City: 380,800 } \\
\text { City area: } 88 \mathrm{~km}^{2} \\
\text { Central density: } \\
4,329 / \mathrm{km}^{2}\end{array}$ & $\begin{array}{l}\text { 1800s period, } \\
\text { public transport } \\
\text { integration }\end{array}$ & $\begin{array}{l}\text { Tram, bus, } \\
\text { trolley bus }\end{array}$ & Hydro power \\
\hline
\end{tabular}


Group codes: Socio-economic hierarchy (SEH), Urban morphology city-wide scale (UMor), Urban structural unit [18] at precinct scale (USU), Urban fabric design (UDes), Urban metabolism (UMet), Mobility and transport system factors (Mob-trans), Energy metabolism flows (Energy-flows), Geographic and climatic factors (Geo). The rankings apply to an oil-constrained future that makes the UMet factors more important for cities as the embodied energy and transport related factors of building materials and petrochemicals increase in priority.

The last step in the open coding process is to establish a core variable. The categorisation suggests the core variable is a combination of USU and UDes that is expressed as sustainable urban form. The urban morphology is not considered to be a candidate, because although it integrates the USU, UDes and UMet, it is a descriptor of the spatial structure and form, rather than a key variable in the development of urban fabric. The urban morphology could be across the entire range of sustainable to completely unsustainable development. The coding leads to a comprehensive definition of urban form to describe the physical entity of an urban area. Sustainable urban form is a set of complex relationships comprising:

- the framework of urban structural units in a hierarchy of scales, transformed within the emerging historical, geographical, ecological and climatic context;

- the urban design - shape, height, density and appearance-of the built environment, including the interface between the built environment and public realm - streets and public spaces, public and private open space;

- mobility and movement hierarchies - networks and transport systems; and

- the urban metabolism supporting, facilitating and sustaining the socioeconomic functionality of a city, including social and cultural processes, metabolic flows of substances, goods, energy and communication within a regenerative ecological footprint.

\subsection{Metabolic relationships of oil-constrained sustainable urban forms}

Axial coding of the data in relation to those variables that relate to the core variable in significant ways articulates a smaller set of higher-level concepts to suggest the qualities of sustainable cities. The result of refining the coding process in the study is the emergence of sub-categories influencing the core category, described as sustainable urban form. The urban morphology group (UMor) and the urban structural unit group (USU) are closely related-UMor at the citywide scale and USU at the smaller precinct scale. The selective coding is framed by three key questions in the context of the European and other studied cities, and tested by a focused interview method with planning experts:

- How might the urban fabric reduce dependence on oil?

- What features of these cities contribute to an efficient urban metabolism?

- Overlaying these aspects, how do these cities perform in providing suitable housing and facilitate mobility of people and transport of food and goods to facilitate social and commercial intercourse? 
Table 2: Categorisation of sustainable city themes and relationships.

\begin{tabular}{|c|c|c|c|c|}
\hline Data summary & Concepts & Group & Relationships & Rank \\
\hline $\begin{array}{l}\text { Politico-economic function } \\
\text { of city in region \& country }\end{array}$ & $\begin{array}{l}\text { Urban hierarchy } \\
\text { scale and city size }\end{array}$ & $\begin{array}{l}\text { Socio-economic } \\
\text { hierarchy (SEH) }\end{array}$ & $\begin{array}{l}\text { SEH influences the } \\
\text { UMor \& investment }\end{array}$ & 1 \\
\hline $\begin{array}{l}\text { Historical development of } \\
\text { city: mono- or multi-centric }\end{array}$ & $\begin{array}{l}\text { Urban transects - } \\
\text { simple or complex }\end{array}$ & $\begin{array}{l}\text { Urban morphology } \\
\text { end result (UMor) }\end{array}$ & $\begin{array}{l}\text { UMor integrates } \\
\text { USUs, UDes, UMet }\end{array}$ & 2 \\
\hline $\begin{array}{l}\text { Street pattern: grid, } \\
\text { concentric, monumental, } \\
\text { haphazard, alleys }\end{array}$ & $\begin{array}{l}\text { Urban form spatial } \\
\text { structures/patterns }\end{array}$ & $\begin{array}{l}\text { Urban structural } \\
\text { unit (USU) } \\
\text { framework }\end{array}$ & \multirow{2}{*}{$\begin{array}{l}\text { USUs relate to UDes, } \\
\text { UMet within UMor } \\
\text { and influence Mob- } \\
\text { trans \& Energy-flows }\end{array}$} & \multirow[t]{2}{*}{1} \\
\hline $\begin{array}{l}\text { Streets, plazas, parks: } \\
\text { move through, socialise in }\end{array}$ & $\begin{array}{l}\text { Urban public realm, } \\
\text { social interaction }\end{array}$ & $\begin{array}{l}\begin{array}{l}\text { Urban structural } \\
\text { unit (USU) form }\end{array} \\
\end{array}$ & & \\
\hline $\begin{array}{l}\text { Block size: short }<100 \mathrm{~m} \text {, } \\
\text { long }>200 \mathrm{~m} \text {, continuity }\end{array}$ & $\begin{array}{l}\text { Built environment } \\
\text { and street interface }\end{array}$ & $\begin{array}{l}\text { Urban fabric and } \\
\text { design (UDes) }\end{array}$ & \multirow{4}{*}{\begin{tabular}{|l|} 
UDes influences and \\
develops USUs and \\
relates to Mob-trans \\
by integrating public \\
transport and the \\
pedestrian network. \\
UDes also influences \\
Energy-flows in the \\
efficient siting and \\
design of buildings \\
\end{tabular}} & \multirow{4}{*}{1} \\
\hline $\begin{array}{l}\text { Walkable streets, direction } \\
\text { finding, focal \& end points }\end{array}$ & $\begin{array}{l}\text { Mobility and legibility } \\
\text { of spatial structure }\end{array}$ & $\begin{array}{l}\text { Urban fabric and } \\
\text { design (UDes) }\end{array}$ & & \\
\hline $\begin{array}{l}\text { Building types: public, } \\
\text { commercial, residential, } \\
\text { churches, monumental }\end{array}$ & $\begin{array}{l}\text { Urban typology for } \\
\text { mixed uses and } \\
\text { apartment living }\end{array}$ & $\begin{array}{l}\text { Urban fabric and } \\
\text { design (UDes) }\end{array}$ & & \\
\hline $\begin{array}{l}\text { Building heights: low 1-3 } \\
\text { storeys, medium 4-8 } \\
\text { storeys, high }>8 \text { storeys }\end{array}$ & $\begin{array}{l}\text { Urban fabric scales: } \\
\text { dense inner urban } \\
\text { development }\end{array}$ & $\begin{array}{l}\text { Urban fabric and } \\
\text { design (UDes) }\end{array}$ & & \\
\hline $\begin{array}{l}\text { Building materials and } \\
\text { sources, road/plaza sealing } \\
\text { and paving surface } \\
\text { materials }\end{array}$ & \begin{tabular}{|l|} 
Building/construction \\
technology, \\
resource \\
conservation \\
\end{tabular} & $\begin{array}{l}\text { Urban metabolism } \\
\text { (UMet): building } \\
\text { flows and stocks }\end{array}$ & \multirow{2}{*}{$\begin{array}{l}\text { UMet relates to USUs } \\
\text { and UMor as the } \\
\text { variables in UDes, } \\
\text { Mob-trans and } \\
\text { Energy-flows that } \\
\text { determine the urban } \\
\text { flows and stocks }\end{array}$} & 2 \\
\hline $\begin{array}{l}\text { Building energy efficiency: } \\
\text { - Embodied energy } \\
\text { - operational energy } \\
\text { - Heating and cooling } \\
\end{array}$ & $\begin{array}{l}\text { Building energy } \\
\text { technology and } \\
\text { conservation }\end{array}$ & $\begin{array}{l}\text { Urban metabolism } \\
\text { (UMet): building } \\
\text { related energy } \\
\text { flows }\end{array}$ & & 2 \\
\hline $\begin{array}{l}\text { Transport evolution: pre- } \\
\text { oil, traffic free areas, trams, } \\
\text { private car or public } \\
\text { transport dominant }\end{array}$ & $\begin{array}{l}\text { Transport } \\
\text { technology and } \\
\text { public-private } \\
\text { investment policies } \\
\end{array}$ & $\begin{array}{l}\text { Mobility and } \\
\text { transport system } \\
\text { factors (Mob- } \\
\text { trans) }\end{array}$ & \multirow{3}{*}{$\begin{array}{l}\text { Mob-trans relates to } \\
\text { UDes and influences } \\
\text { USUs; and critically } \\
\text { depends on Energy- } \\
\text { flows. Types of public } \\
\text { transport are } \\
\text { determined by the } \\
\text { urban public policies } \\
\text { \& investments. Mob- } \\
\text { trans is also inter- } \\
\text { urban \& international }\end{array}$} & 3 \\
\hline $\begin{array}{l}\text { Public transport types: } \\
\text { trams, light rail, heavy rail, } \\
\text { electric trolley buses, } \\
\text { fossil fuel powered buses }\end{array}$ & $\begin{array}{l}\text { Transport systems } \\
\text { and networks and } \\
\text { public investment } \\
\text { policies }\end{array}$ & $\begin{array}{l}\text { Mobility and } \\
\text { transport system } \\
\text { factors (Mob- } \\
\text { trans) } \\
\end{array}$ & & 3 \\
\hline $\begin{array}{l}\text { Traffic hierarchy: prime } \\
\text { vehicle access, shared } \\
\text { pedestrian-vehicular } \\
\text { traffic, pedestrian }\end{array}$ & $\begin{array}{l}\text { Movement \& } \\
\text { mobility hierarchies: } \\
\text { can put cars or } \\
\text { people first }\end{array}$ & $\begin{array}{l}\text { Mobility and } \\
\text { transport system } \\
\text { factors (Mob- } \\
\text { trans) }\end{array}$ & & 5 \\
\hline $\begin{array}{l}\text { Energy for light \& power: } \\
\text { conventional, renewables }\end{array}$ & $\begin{array}{l}\text { Stationary energy } \\
\text { technology }\end{array}$ & \multirow{2}{*}{$\begin{array}{l}\text { Energy metabolic } \\
\text { flows (Energy- } \\
\text { flows) }\end{array}$} & \multirow{2}{*}{$\begin{array}{l}\text { Energy-flows depend } \\
\text { on energy resources } \\
\text { available to the city \& } \\
\text { renewables (e.g. PV) } \\
\end{array}$} & 4 \\
\hline $\begin{array}{l}\text { Energy for transport: fossil } \\
\text { fuels, renewable sources }\end{array}$ & $\begin{array}{l}\text { Transport energy } \\
\text { technology }\end{array}$ & & & 3 \\
\hline $\begin{array}{l}\text { Water connection: riverine } \\
\text { or coastal topography \& } \\
\text { location }\end{array}$ & \multirow{2}{*}{$\begin{array}{l}\text { Geographic and } \\
\text { climatic context: e.g. } \\
\text { for urban design \& } \\
\text { renewable energy }\end{array}$} & \multirow{2}{*}{$\begin{array}{l}\text { Geographic and } \\
\text { climatic factors } \\
(\text { Geo) }\end{array}$} & \multirow{2}{*}{$\begin{array}{l}\text { Geo influences UDes, } \\
\text { UMet, Energy-flows } \\
\text { \& UMor of the city }\end{array}$} & 3 \\
\hline Climatic context of city & & & & 4 \\
\hline
\end{tabular}


The grounded theory selective coding process is not shown in this paper, but results in an integrated conceptual framework at Figure 1. It shows the relationships between the selected categories in the context of an oil-constrained scenario. The central phenomenon sustainable urban form (P2) has properties and dimensions. The causal condition is oil depletion (P1), modified by geographic/climatic context, which affects the sustainable urban form phenomenon to produce a desired outcome (P3), analogous to an oil-constrained sustainable urban form. Of course, undesirable outcomes are also possible-but are not shown in the model-which would result in unsustainable urban forms.

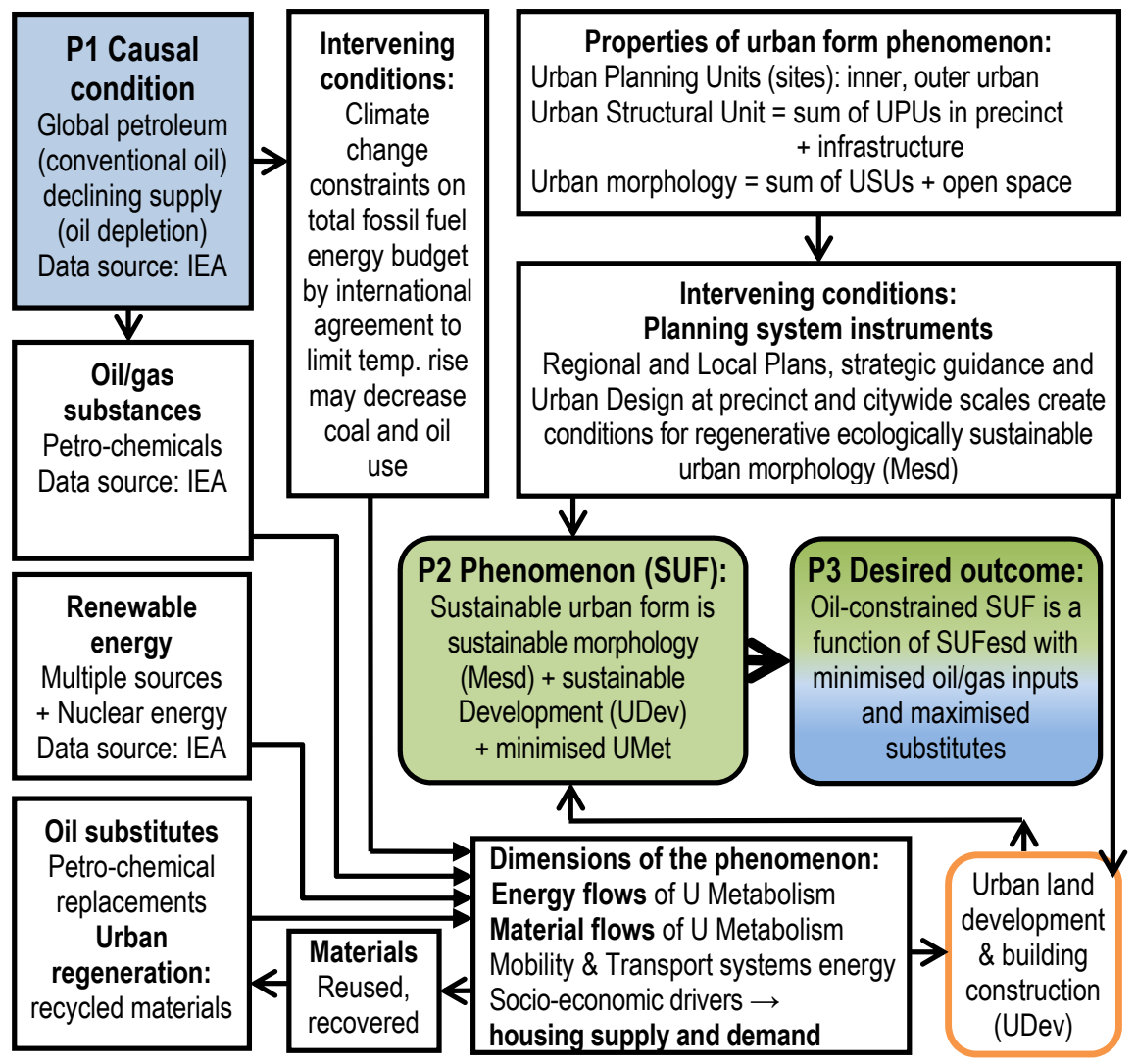

Figure 1: Integrated conceptual framework for relationships between oil-related inputs and oil-constrained sustainable urban forms.

\section{Pathways to more sustainable cities}

The foregoing analysis is based on the study of existing cities developed in the pre-oil economy and supplemented by knowledge of, and exposure to, modern cities that have different urban forms. Some of the latter cities are closer in form 
to the City of Gold Coast that has a large suburban structure, such as Portland, Oregon USA. Although the European model is considered to provide valuable insights to the future post-oil economy, the characteristics need to take into account the Queensland planning and development context and the regional subtropical climate. The framework in Figure 1 provides the basis of a tool for integrating the effects of oil constraints into the urban metabolism for sustainable planning and development. The themes identified in section 2.2 are a useful starting point to propose hypotheses arising from the grounded theory analysis. Some of these qualities may not be directly planning related, but should be included in making a strategic transformation to an oil-constrained city.

\subsection{Oil-constrained sustainable cities characteristics}

The planning-related characteristics of a sustainable city under a scenario of oil constraints can be distilled into a narrative about the modified phenomenon P3. An oil-constrained sustainable city is likely to have the following characteristics:

A. Urban development is contained within well-defined boundaries to facilitate densification and public transport, and outward expansion is curtailed by planning policies and transport factors. The city-wide urban form is compact and thus conducive to active (walking and cycling) mobility for everyday activities.

B. Low density residential development is limited by planning policies, but detached houses are acknowledged as efficient energy forms in suitable locations, particularly in the outer suburban segments of the urban transect. This area is gradually transformed into a productive urban living/horticulture zone, facilitated by transferrable development rights legislation or planning codes.

C. Central and nodal activity centres are planned as integrated mixed use, three-dimensional eco-architectural systems to fully exploit the residential opportunities in a range of medium rise development, while preserving solar access. Residential towers are located in suitable locations, such as at focal points and in areas of existing towers. The strategy is implemented as a planning policy in cooperation with the private development sector, supported by public awareness through community engagement programs. Piecemeal development extending from the activity nodes is minimised by infrastructure scheduling.

D. Urban design planning for dense development features small block sizes, semi-continuous street façades, with active frontages and harmonious streetscape. Green street design with tree planting and a hierarchy of road widths limits cars in narrow streets. A network of landscaped plazas with seating, interesting art and fountain features, create pleasant spaces to meet and add to the legibility of cities. These features facilitate walking and low energy assisted mobility to extend the comfortable radius to 1015 minutes or about $1 \mathrm{~km}$ (allowing for street crossings).

E. Medium rise-high density apartment buildings are a preferred type of urban residential development as an alternative to detached houses. This alternative is associated with a cultural acceptance of such urban design 
form in European cities, but may only gradually increase over time in the Australian context, unless planning policies incentivise this form.

F. The city is well serviced by multiple forms of public transport, including surface and underground systems, which are tightly coordinated with high frequency operation, and incorporate active modes. The land usetransport system is designed to transform most of the city effectively for a public-active transport oriented development (P-ATOD) focus that promotes and realises densification in ways that go beyond current transit oriented development (TOD) spatial and density parameters. Precincts are more focused on 'place' than 'transit'.

G. Private car transport usage is reduced by oil-constraints and active transport — walking and cycling — is prioritised. Shared traffic-pedestrian low speed zones are integrated with public transport routes in central and nodal activity centres.

H. Comprehensive building codes support the innovative design of low embodied and operational energy-efficient buildings with high insulation standards (e.g. PassivHaus where climatically effective). Technological innovation and inventions include non-oil-based building materials and construction methods.

I. Vernacular architecture in residential building design and materials is promoted to use local materials, reduce cement consumption, conserve resources and facilitate off-site manufacture of materials and components. Off-site manufacture eases the transport-related labour element of construction problems and is integrated into the three dimensional eco-architectural system suggested above.

J. The city has a comparatively reduced ecological footprint by the combination of regenerative urban and hinterland ecology, renewable resource cultivation, hinterland horticulture, urban community gardens and building based farming.

K. Embodied and operational energy considerations imply that high rise central city and TOD type developments may be more vulnerable than low-medium rise buildings, with negative implications for the concept of high rise oriented 'compact urban form' (e.g. Droege [4], Newman et al. [5]). It has been suggested that the peak oil plateau possibly could also be the peak of urban development. Such a notion runs counter to technofuture oriented architects who envisage vast three-dimensional cities of skyscraper towers (e.g. Broto [17]).

L. Renewable energy sources gradually make the city independent of the oil-economy both in manufacture of components and in operation of the built environment. This implies that solar and wind based powered technology eventually is capable of constructing and operating locally distributed electrical systems. Gas is used as an interim solution to fire power stations while the renewable base load systems are developed (such as concentrating solar thermal arrays in Australia).

M. In the constrained phase of oil depletion, the movement of people, goods and materials requires complex reorganisation of resources under the 
guidance of governments. Strategies implement renewable stationary energy and alternative automotive power technology away from reliance on oil- and gas-based solutions. The public transport system is fully developed during the adaptation phase and light rail and bus routes can be used to transport goods at night time to internal distribution points. Liquid and pneumatic pipelines can move continuous supplies of substances and small containerised goods.

\subsection{Oil-constrained sustainable urban form propositions}

The grounded theory method of building theories generates concepts grounded in the data and proposes hypotheses for evaluation. The purpose of the research is to establish the best fit of concepts to a set of indicators. In this study, all the above indicators are interrelated — so are included in the set—-but some have more direct relevance to the research problem, which focuses on urban residential form. It is considered prudent to reduce the set to the most relevant indicator properties. Glaser and Holton [16] suggests that such 'reduction occurs when the analyst discovers underlying uniformity in the original set of categories or their properties and then reformulates the theory with a smaller set of higher level concepts' (p. 10). The following propositions are made, associated to the most relevant concepts from the coding, recompiled as indicators in matrix at Table 3:

1. The effects of oil constraints relating to sustainability of land development and building construction occur across the typology of urban residential forms;

2. The significance of oil constraints operates at various scales of the urban structural units and the relevant building-related energy flows;

3. The significance of oil constraints relates to urban expansion (sprawl);

4. The influence of oil constraints influences land use planning policies in relation to sustainable urban residential forms, within the Australian urban context.

\subsection{Grounded theories relevant to oil-constrained sustainable cities}

Validation of the grounded theoretical concepts in the study results in the following four grounded theories being proposed to explain the effects that possible future oil constraints may have on urban residential development, and hence their relationship to the planning of urban forms in the context of a twentieth century Australian coastal city. The theories operate at different scales of the urban form and acknowledge a timing sequence in their relevance and application. This suggests strategic planning in two phases: towards a transitional city of tomorrow and an oil-constrained city of the future. The four theories are:

1. Oil supply constraints will gradually affect all types of urban residential buildings at the site scale:

Oil supply constraints potentially affect the sustainability of all new land development and construction of all types of urban residential buildings to varying extents, depending on the materials used and transport-related factors. Materialsrelated vulnerability may be reduced by adaptation to non-petroleum substitutes. 
Transport-related vulnerability may be reduced by conversion of diesel powered vehicles and machinery to available replacement 'fuels' as a mitigation strategy in the short-medium transitional phase.

Table 3: Matrix of relevant indicators to sustainable urban residential forms.

\begin{tabular}{|c|c|c|c|c|}
\hline \multirow{2}{*}{ Relevant indicators in section 3.1 : } & \multicolumn{4}{|c|}{$\begin{array}{l}\text { Significant to } \\
\text { propositions: }\end{array}$} \\
\hline & 1 & 2 & 3 & 4 \\
\hline A: Well-defined urban planning boundaries to facilitate densification & $\diamond$ & & $\diamond$ & $\checkmark$ \\
\hline B: Low density residential development is limited by planning policies & $\diamond$ & & $\diamond$ & $\diamond$ \\
\hline C: Activity centres are planned as mixed-use 3-dimensional development & $\diamond$ & $\diamond$ & & $\checkmark$ \\
\hline D: Urban design/planning for dense development & $\diamond$ & $\diamond$ & & $\diamond$ \\
\hline E: Medium rise/high density apartment buildings a preferred type & $\diamond$ & $\diamond$ & & $\diamond$ \\
\hline F: Multiple forms of P-ATOD with appropriate densification of urban form & $\diamond$ & $\diamond$ & $\diamond$ & $\diamond$ \\
\hline G: Shared traffic-pedestrian low speed zones supporting active transport & & $\diamond$ & & $\diamond$ \\
\hline H: Building codes support innovative design; energy-efficient buildings & $\diamond$ & & & $\diamond$ \\
\hline I: Vernacular architecture in residential buildings; off-site manufacture & $\diamond$ & $\diamond$ & & \\
\hline J: Reduced urban ecological footprint; urban farming & $\diamond$ & & $\diamond$ & $\diamond$ \\
\hline K: High rise residential towers embodied and operational energy issues & $\diamond$ & $\diamond$ & & $\diamond$ \\
\hline L: Renewable energy sources become independent of the oil-economy & $\diamond$ & $\diamond$ & & \\
\hline $\begin{array}{l}\text { M: Government guided integrated transformation strategies for renewable } \\
\text { energy and alternative transport energy sources and distribution }\end{array}$ & $\diamond$ & & $\diamond$ & $\diamond$ \\
\hline
\end{tabular}

2. Adaptive design is needed for sustainable urban residential forms at the precinct scale:

Adaptive design for oil-constrained sustainable urban residential forms at the precinct scale of urban structural units is facilitated most efficiently by medium rise-high density apartment buildings arranged as perimeter blocks; to achieve objectives for building material and energy flows, urban density, adaptable functionality, and public-active transport oriented development.

3. Oil depletion will increasingly affect urban communities at middle-outer city scales:

The transport-related mitigation phase of oil depletion will increasingly inhibit suburban sprawl led city-wide expansion and accelerate redevelopment pressure in inner urban serviced areas close to public transport. In the later adaptive phase, availability of system-wide alternative energy powered vehicles may mitigate mobility and living cost issues in more affordable housing in existing middleouter suburbs.

4. Transformative planning system policies are needed at city-wide and regional scales:

As the phenomenon of oil depletion gains international acceptance as a wicked global problem, it will influence government urban land use policies at both city- 
wide and regional scales within the State and Australian planning system context. Transformative guidance on urban metabolic energy flows is linked to state and national policies on transport, renewable energy and climate change mitigation. Detailed implementation of inner urban serviced area redevelopment to promote mixed use at higher densities would be subject to planning provisions to suit local conditions, including strategic guidance in oil depletion adaptation policies. Implementation of the transformation is critically dependent upon community acceptance and support for the paradigm shift.

\section{Conclusion}

European pre-oil economy cities form a viable basis for developing grounded theories and a conceptual framework on the characteristics of a sustainable city in an oil-constrained scenario. These tools will assist in planning cities in two phases: a transitional city of tomorrow and an oil-constrained city of the future.

\section{References}

[1] United Nations Human Settlements Programme 2009, Planning sustainable cities: global report on human settlements, Earthscan, London, p. 5, 2009.

[2] Bruegmann, R., Sprawl: a compact history, University of Chicago Press, Chicago, 2005.

[3] Brewster, R.J., 'Significance of global oil depletion to urban residential development', in CA Brebbia (ed.), Sustainability today, WIT Press, Southampton, pp. 151-163, 2012.

[4] Droege, P., The Renewable City: a comprehensive guide to an urban revolution, Wiley-Academy, Chichester, p. 160, 2006.

[5] Newman, P. Beatley, T. \& Boyer, H., Resilient Cities: responding to peak oil and climate change, Island Press, Washington, D.C., pp. 4 and 21, 2009.

[6] Brewster, R.J., 'Pathways to an oil-constrained future: analogies with climate change mitigation and adaptation', in CA Brebbia (ed.), Sustainable Development and Planning VI, WIT Press, Southampton, pp. 253-265, 2013.

[7] International Energy Agency (IEA), World Energy Outlook 2010, International Energy Agency and Organisation for Economic Cooperation and Development (OECD), Paris, p. 6, 2010.

[8] IEA, World energy outlook 2013: Executive Summary, International Energy Agency and OECD, Paris, pp. 4-5, 2013.

[9] Gehl, J., Cities for people, Island Press, Washington, 2010.

[10] Girardet, H., Cities people planet: urban development and climate change, 2nd edn, John Wiley \& Sons, Hoboken, New Jersey, 2008.

[11] Lynch, K., Good City Form, MIT Press, Cambridge, Massachusetts, 1984.

[12] Krier, R., Urban space, Rizzoli, New York, 1979.

[13] Ng, E. (ed.), Designing high-density cities for social and environmental sustainability, Earthscan, London, 2010. 
[14] Osmond, P., The urban structural unit: towards a descriptive framework to support urban analysis and planning. Urban Morphology, 14(1), pp. 5-20, 2010.

[15] European Commission, Cities of tomorrow: challenges, visions, ways forward, European Commission Directorate General for Regional Policy, Brussels, doi: 10.2776/41803, 2011.

[16] Glaser, B.G. \& Holton, J., 'Remodelling grounded theory', Forum: Qualitative Social Research, vol. 5, no. 2, 2004, urn:nbn:de:0114-fqs040245

[17] Broto, E., High density environments for the future, Carles Broto i Comerma, Barcelona, Spain, 2010. 